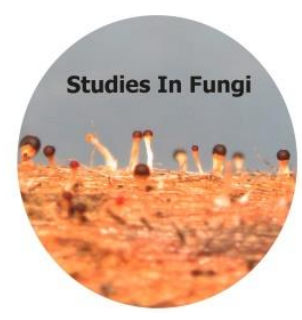

Studies in Fungi 2 (1): 178-190 (2017) www.studiesinfungi.org ISSN 2465-4973

Article

Doi 10.5943/sif/ 2/1/20

Copyright $\odot$ Mushroom Research Foundation

\title{
In vitro post-harvest growth parameters of termite-associated fungi: a case study of Termitomyces schimperi (Basidiomycota, Lyophyllaceae)
}

\author{
Essouman EPF, Kengni Ayissi MB, Metsebing BP and Mossebo DC
}

University of Yaoundé 1, Mycological Laboratory, B.P. 1456 Yaoundé, Cameroon

Essouman EPF, Kengni Ayissi MB, Metsebing BP, Mossebo DC 2017 - In vitro post-harvest growth parameters of termite-associated fungi: a case study of Termitomyces schimperi (Basidiomycota, Lyophyllaceae). Studies in Fungi 2(1), 178-190, Doi 10.5943/sif/2/1/20

\begin{abstract}
Post-harvest growth parameters of the pileus of three immature sporocarps $\left(\mathrm{Y}_{7}, \mathrm{Y}_{8}, \mathrm{Y}_{10}\right)$ of Termitomyces schimperi showing margins still attached to the stipe by the veil upon collection were studied in order to determine the optimum temperature, air moisture and maximum time at which they continue to grow after collection until opening their hymenophore, giving access to more mature lamellae able to produce spore-prints and more relevant for other studies. The figures obtained from the three equations $\left(Y_{7}=0.7+0.1 x ; Y_{8}=1.98+0.225 x ; Y_{10}=-0.94+0.116 x\right)$ of correlation between pileus post-harvest growth and time show various growth patterns depending on morphology, physiology and metabolism of each of the three sporocarps ( 3 replicates: $\mathrm{Y}_{7}, \mathrm{Y}_{8}$ and $\mathrm{Y}_{10}$ ) tested in vitro. The experiment also shows that, while the size of the stipe of T. schimperi remains constant in the three replicates, its pileus continues to grow for about $36 \mathrm{hrs}$ maximum after collection and its diameter increases of about $3.23 \mathrm{~cm}$ to $10.08 \mathrm{~cm}$ in an environment of darkness with temperature ranging between $23^{\circ} \mathrm{C}$ and $24^{\circ} \mathrm{C}$ and relative humidity between $88 \%$ and 92\%. Considering on the one hand that gill-fungi in general and Termitomyces in particular are highly perishable goods, and on the other hand that sporocarps of Termitomyces are not yet raised in artificial culture, this experiment shows that during mycological excursions, even when sporocarps of these species are found immature on the field, they should also be collected for study since a post-harvest growth of the pileus of numerous species could be artificially triggered or boosted in the laboratory in order to be able to obtain spore-prints important at various levels, and also get access to more mature lamellae absolutely necessary for further studies including particularly the macro- and microscopical descriptions prior to identification. Mature lamellae are also most often the best part used in gill-fungi for DNA extraction in molecular studies.
\end{abstract}

Key words - correlation - environment - immature sporocarps - mature hymenium - spore prints - termitophilic fungi

\section{Introduction}

The genus Termitomyces R. Heim includes a group of paleotropical and good edible mushrooms (Mossebo \& Njouonkou 2010, Kansci et al. 2003) sharing together some common ecological and morphological features, the most conspicuous of which being the obligate symbiotic association with termites belonging to the subfamily Macrotermitinae, the presence of a more or less conspicuous umbo called perforatorium which is pointed in some species and believed to help 
the basidiome forging its way out of the soil during growth, and the presence of a pseudorhiza which is a thread-like subterranean elongation of the stipe in connection with combs built by termites in giant or subterranean termites nests. Since this genus was erected by Heim (1942) with 10 species and 6 forms, several other taxa mainly from Africa and Asia have been described and documented by several authors including Heim (1958, 1977), Mossebo (2000, 2002), Mossebo et al. (2002, 2006, 2009, 2011, 2017), Natarajan (1979), Otieno (1964), Pegler (1977), Piearce (1987), Pegler \& Vanhaecke (1994), Saarimäki et al. (1994), Tang et al. (2005, 2006), Turnbull \& Watling (1999), Van der Westhuizen \& Eicker (1990), Wei et al. (2004). An estimate of about 30 species (Kirk et al. 2008) of Termitomyces have so far been described worldwide, some of which being specific to tropical Africa, others to parts of Asia and some few common to these two regions of the world (Mossebo et al. 2017). Singer (1986) also reported Termitomyces in some regions of the South Pacific. In a contribution to further improve the state of knowledge of African species, Mossebo et al. $(2002,2009,2011)$ documented 18 records of Termitomyces from Cameroon and central Africa. However, all the above mentioned contributions from various authors were done only on the basis of macro- and micromorphological features. The first molecular and phylogenetic studies on Termitomyces are relatively recent, the most noteworthy being those of Rouland LeFevre et al. (2002), Aanen et al. (2002), Taprab et al. (2002), Frøslev et al. (2003), Sawhasan et al. (2011), Oyetayo (2012), Saré et al. (2014) and Mossebo et al. (2017).

Taxonomic studies of gill-fungi in general including Termitomyces are preferably carried out on mature sporocarps or fruit bodies for a reliable description of their macroscopic and microscopic features. However, during collection, it sometimes happens that sporocarps of these species are found immature on the field. Considering that gill-fungi are generally highly perishable goods and most often start deteriorating not long, sometimes within just few hrs after collection according to numerous authors including Burton et al. (1987), López-Briones et al. (1992, 1993), Roy et al. (1996) \& Tano et al. (1999), they furthermore have a generally short life span of just some few hrs or days according to these authors. For the above mentioned reasons, sporocarps of Termitomyces and other gill-fungi should preferably be collected mature on the field considering that collection on the spot can most often not be delayed for many reasons. These reasons include the high risk of not finding them anymore or already rotten on the growing spot if collection is postponed days after. However, these sporocarps are usually also found immature and immature lamellae from hymenophore are irrelevant particularly for micro-morphological descriptions and are generally unable to produce spore-prints. These spore-prints are yet necessary for a relevant description including color, spores features sometimes unavailable in lamellae of some species, as well as spore culture for the studies of cultural characters. Termitomyces schimperi (Pat.) R. Heim in particular, when immature shows a subglobose, hemispherical or subhemispherical pileus (Heim 1977, Mossebo et al. 2002) most often still attached to the stipe by the veil. These morphologies (Fig. 2 $(\mathrm{C} 1, \mathrm{~B} 2, \mathrm{~A} 1)$ ) give no direct access to the lamellate hymenophore in order to detach lamellae. They also offer no possibility of obtaining spore-prints. Therefore and whenever possible, an additional growth of these immature sporocarps should be boosted or artificially triggered in order to obtain more mature sporocarps and internal structures including the hymenium.

Post-harvest growth of sporocarps have already been observed and studied in some species (Ares et al. 2007, Henze 1989, Moore 1984) but not yet in the genus Termitomyces. These studies followed observations that young sporocarps of some species of gill-fungi in particular continue to develop even after they were separated from the generating mycelium (Hammond 1979) on substrate. Considering Agaricus bisporus in particular, Hammond (1979) affirms that its sporocarp continues to develop for some time in post-harvest growth exactly as when it was still on the cultivation substrate which was compost. Braaksma et al. (1998) furthermore says that during postharvest growth, stipe of Agaricus bisporus (J.E. Lange) Imbach continue to grow in length, pileus enlarges, lamellae are formed followed by spores production. Moore (1984) observed the same development in Coprinus cinereus (Schaeff: Fr.) Gray. Considering that such studies have never before been carried out on Termitomyces in general and T. schimperi in particular, it appeared necessary, in case immature sporocarps of these species and other macromycetes are collected on 
the field, to also develop strategies in order to trigger or boost their post-harvest growth and pileus in particular, the aim being the accurate determination of the optimal time and other environmental parameters essential for the improvement of the stage of maturity of the cap and hymenial structures and also trigger the cap-opening in order to obtain spore-print. The research work carried out consisted of setting up an experimental device in which a specific environment was created in vitro in order to determine the optimum temperature and relative humidity (air moisture) for postharvest growth and thereafter correlate pileus diameter and time at which immature pileus of $T$. schimperi continues to develop for the above mentioned purposes.

\section{Materials \& methods}

\section{Materials}

The study was carried out using three immature specimens $\left(\mathrm{Y}_{7}, \mathrm{Y}_{8}, \mathrm{Y}_{10}\right)$ of $T$. schimperi as the three replicates (Figs 2 (C1, B2, A1)) of the experiment. They were either collected or bought fresh on order the same day of their collection by farmers in three different food markets in Yaoundé (capital of Cameroon). Other material used included: a hard-paper box (Fig. 1A) of about $25 \mathrm{~cm}(\mathrm{~L}) \times 15 \mathrm{~cm}(\mathrm{l}) \times 15 \mathrm{~cm}(\mathrm{H})$ (could be bigger depending on the size and number of specimen to be tested at a time) with the 4 sides of the top cover folded inside in order to transform the box into a damp chamber; a VWR (EU 620-0195 NA 82021-166) hygro-thermometer clock (Figs $1\left(\mathrm{~F}_{1}\right.$, $\left.\mathrm{F}_{2}, \mathrm{~F}_{3}\right)$ \& Fig. $\left.1 \mathrm{H}\right)$ with outdoor sensor $\left(\mathrm{Fig} .1 \mathrm{~F}_{3}\right)$ to monitor the temperature and relative humidity (air moisture) in the damp chamber; a tape meter (Fig. 1G) to measure the size of the pileus in postharvest growth, a water sprayer (Fig. 1E), a thick towel (Fig. 1D) and tap water.

\section{Methods}

Once the 4 sides of the top cover of the hard-paper box were folded inside (Fig. 1A), the sprayer was filled up with tap water also used to thoroughly wet the towel. The wire outdoor sensor of the hygro-thermometer clock was thereafter connected (Fig. $\left.1 \mathrm{~F}_{2}\right)$ to the device $\left(\right.$ Fig. $\left.1 \mathrm{~F}_{1}\right)$. Stipe of sporocarps were thoroughly cleaned under flowing tap-water in order to get rid of eventual soil or dirty remains from collection area and thereafter set for a while to dry at the laboratory temperature $\left(25-28^{\circ} \mathrm{C}\right)$. The entire immature sporocarps (Fig. $1(\mathrm{~B}, \mathrm{C})$ ) were then placed at the middle-bottom of the box and the hygro-thermometer sensor tip (Fig. $1 \mathrm{~F}_{3}$ ) placed within, near the sporocarps.

After the hygro-thermometer was switched on and placed some centimetres away (Fig. $\left.1 \mathrm{~F}_{1}\right)$ from the box, the box content was thoroughly sprayed with tap-water in the sprayer and immediately after, covered with the wet towel in order to keep a high relative humidity and darkness around the sporocarps in the box. Preliminary experimental trials with temperatures ranging from $20^{\circ} \mathrm{C}$ to $28^{\circ} \mathrm{C}$ and relative humidity from $65 \%$ to $92 \%$ showed that the optimum temperature and air moisture for a maximum post-harvest growth of the pileus in the damp chamber ranged respectively between $23^{\circ} \mathrm{C}$ to $24^{\circ} \mathrm{C}$ and $88 \%$ to $92 \%$. The role of the hygrothermometer was to directly monitor these figures from outside the damp chamber and whenever the relative humidity in particular dropped to less than $88 \%$, the towel was removed and once more slightly dipped in tap water and the damp chamber containing the sporocarps once more sprayed with water from sprayer before being covered again with the wet towel. The launching time of the experiment was noted on the clock of the hygro-thermometer and at regular interval of about 6 hrs, the growth in diameter and the differential diameter size of the pileus was measured with the tape meter (Fig. 1G) and noted. These figures were thereafter used to compute the correlation equations (Fig. 4) between pileus post-harvest growth and time, followed by the analysis of the histograms (Fig. 3) and regression lines (Fig. 4) obtained. 

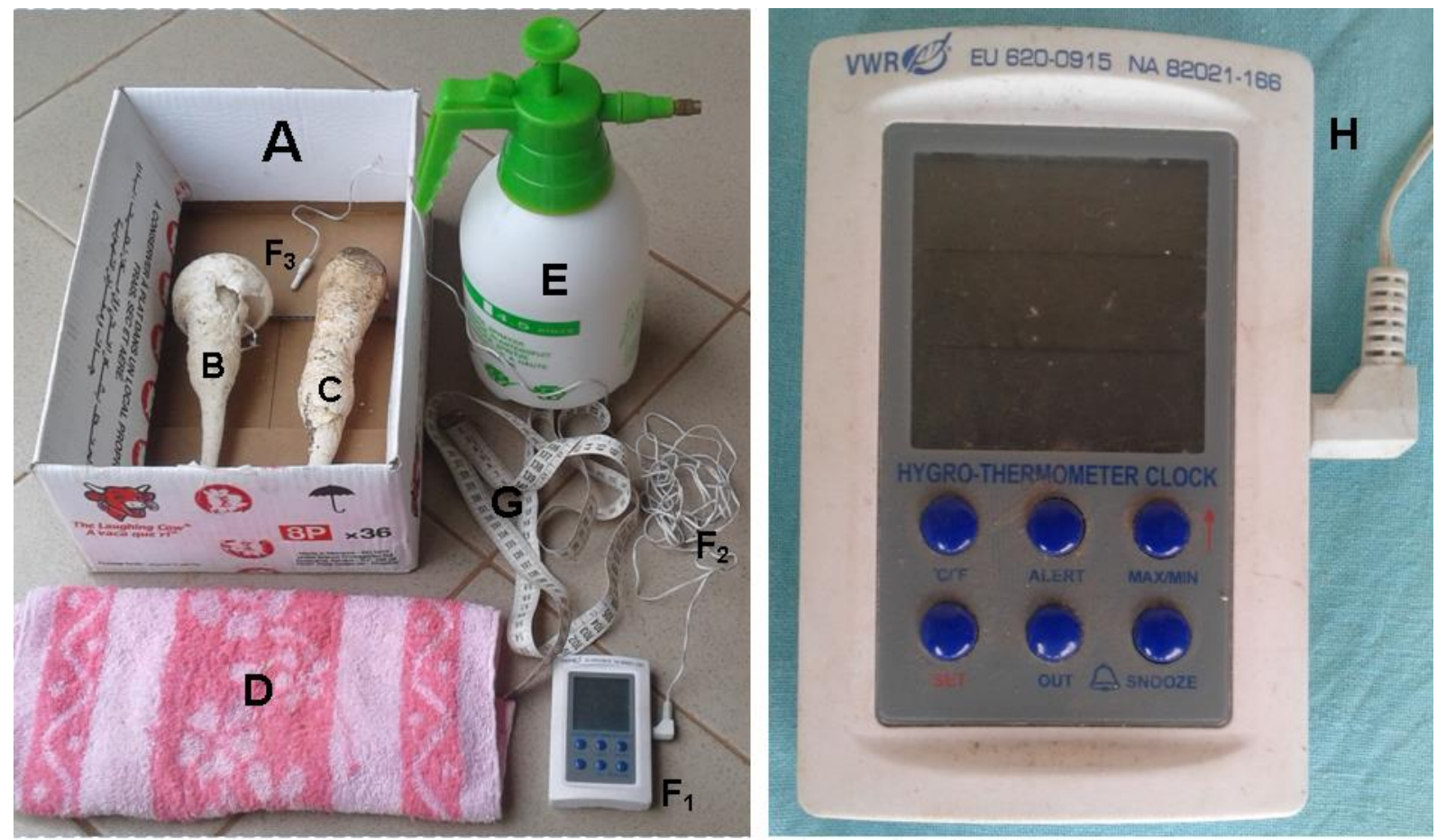

Photograph D. C. MOSSEBO

Photograph D. C. MOSSEBO

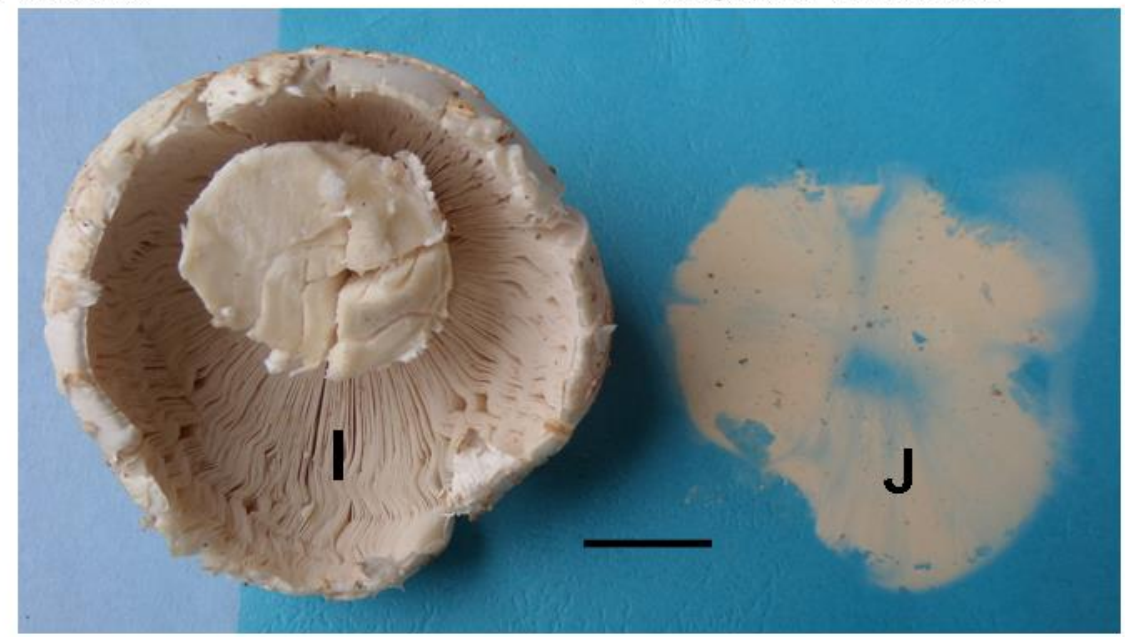

Photograph D. C. MOSSEBO

Fig. 1 - Material used for the post-harvest growth experiment in vitro and pileus hymenophore of T. schimperi with spore-print collected after post-harvest growth. A Open carton in hard-paper. B-C Immature sporocarps of T. schimperi collected on the field. D Towel. E Water sprayer. F1-F3 Hygro-thermometer clock with outdoor sensor $\left(\mathrm{F}_{3}\right)$. $\mathrm{G}$ Tape meter. $\mathrm{H}$ Zoom on the hygrothermometer clock (Brand VWR: EU 620-0195 NA 82021-166). I Pileus hymenophore with more mature lamellae after $36 \mathrm{hrs}$ post-harvest growth. J Spore-print collected from pileus after postharvest growth.

\section{Results}

\section{Correlation between time and post-harvest growth of the pileus and its mycological interest}

Images on Fig 2 and post-harvest growth data recorded in Table 1, $2 \& 3$ and thereafter computed in histograms (Fig. 3) and regression lines (Fig. 4) for each of the 3 replicates show \pm important differences in their evolution in post-harvest growth. Considering first the specimens $\mathrm{N}^{\circ}$ 7 and 8, they show (Figs. 2, $3 \& 4$ ) a steady growth of the pileus diameter in the first 12 to 24 hrs after launching the experiment with key phases such as the breaking (Figs. $2(\mathrm{C} 1, \mathrm{C} 2)$ and 

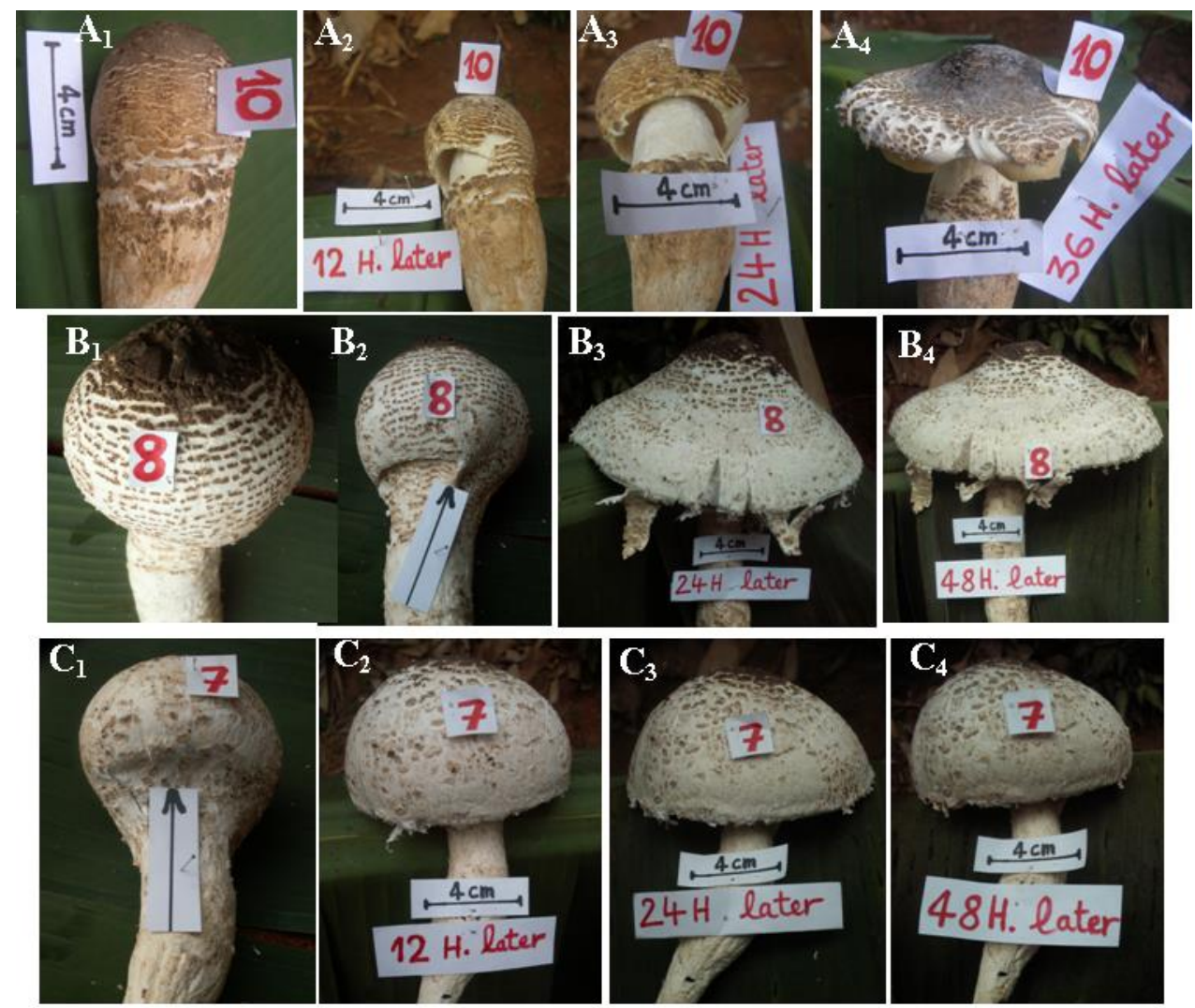

Photograph D.C. MOSSEBO

Fig. 2 - Monitoring of the increasing growth in diameter (A1-A4, B1-B4, C1-C4) in vitro of the pileus of $T$. schimperi collected immature in 3 replicates (specimens $\mathrm{Y}_{7}(\mathrm{C}), \mathrm{Y}_{8}(\mathrm{~B}) \& \mathrm{Y}_{10}(\mathrm{~A})$ ).

Figs. 2 (B2, B3)) of the veil (Figs. 2 (C1-B2)/arrow) from the pileus, followed by the enlargement of the pileus diameter, changing from subglobose (Fig. 2C1) to subhemispherical (Fig. 2C4) for specimen 7 and from subglobose (Fig. 2B2) to convex (Fig. 2B4) for specimen $\mathrm{N}^{\circ} 8$. It is worth mentioning that the convex and subhemispherical forms of the pileus enabled the collection of spore-print (Fig. 1J), impossible to obtain with the original subglobose forms (Figs 2 (B2, C1)). Histograms on Figure 3 and data on differential growth in pileus diameter show that for specimen $\mathrm{N}^{\circ} 7 \& 8$ in particular, pileus growth slows down a bit between the $24^{\text {th }}$ and $36^{\text {th }} \mathrm{hr}$ and generally stops completely around the $36^{\text {th }} \mathrm{hr}$ after launching the experiment, considering that diameters recorded at the $48^{\text {th }} \mathrm{hr}$ (Figs. 2 (C4, B4)) and more, did not evolve from that recorded at the $36^{\text {th }} \mathrm{hr}$. Elsewhere, considering specimen $\mathrm{N}^{\circ} 10$, its evolution pattern somewhat differs from that of specimen $\mathrm{N}^{\circ} 7$ and 8 in that its post-harvest growth is relatively slow as shown on Figures 2 (A1, A2, A3), Figure 3 and data in Table 3 from the $1^{\text {st }}$ to the $24^{\text {th }} \mathrm{hr}$ of the experiment and its pileus (Figs. 2 (A3, A4)) developed essentially between the $24^{\text {th }}$ and $36^{\text {th }} \mathrm{hr}$ when it became convex to plano-convex with an opened hymenophore giving an easier access to more mature lamellae.

The preliminary conclusion from the above mentioned observations and data recorded is that when the surrounding temperature and relative humidity are suitable, pileus of immature sporocarps of $T$. schimperi can continue to grow in diameter for a maximum time of about $36 \mathrm{hrs}$ when they are set in a suitable environment including darkness, temperature ranging between $23^{\circ} \mathrm{C}$ and $24^{\circ} \mathrm{C}$ and relative humidity between $88 \%$ and $92 \%$. Figures presented in Table 4 show that in such an environment, during the 36 hrs post-harvest growth, the pileus diameter could potentially increase from 3.23 to $10.08 \mathrm{~cm}$ with an average augmentation of $5.87 \mathrm{~cm}$. This experiment using $T$. schimperi as model led among others to the gain of a more mature pileus (Fig. 1I), weighing a little bit more than it was on the collection spot, what somewhat represents a gain in quantity of consumable flesh - able to produce spore-print (Fig. 1J) from more mature lamellae (Fig. 1I), sporeprints being absolutely necessary for further studies including crossings in sexual reproduction and 
raising of mycelia in artificial culture in some species. Also, the development of the pileus along with the opening of its lamellate hymenophore following the morphological evolution (Figs. 1 (B, C) $\neq$ Figs 1 (A4, B4, C4) and Fig. 1I) gave access to lamellae which could henceforth be easily collected for further studies including the study of microscopical features as well as molecular phylogenetic studies, considering that mature lamellae are usually the best part used for DNA extraction in gill-fungi. Considering the above mentioned scientific benefits from the experimental protocol described and particularly suitable for Termitomyces schimperi, the experiment could be easily extended to some other taxa of Termitomyces and numerous other species of gill-fungi which are well known by field mycologists as sometimes found still immature on the field during mycological excursions, but must nevertheless be collected in that state, since they are known to be highly perishable goods (compared to carpophores of most Polyporales and similar groups of mostly annual to perennial species which are known to be generally more resistant and last longer) and their fast to very fast growing nature is such that their collection could generally not be postponed for later.

The potential average growth of pileus diameter of the 3 specimens (replicates) of $T$. schimperi after 36 hrs of post-harvest growth is given below in Table 1:

Table 1 Potential growth range in vitro of pileus diameter of three sporocarps (specimen $\mathrm{N}^{\circ} 7, \mathrm{~N}^{\circ} 8$ and $\mathrm{N}^{\circ} 10$ as three replicates) of $T$. schimperi collected immature, based on the correlation equations and the indicative maximum ( $36 \mathrm{hrs}$ ) post-harvest time of growth.

\begin{tabular}{|c|c|c|c|}
\hline Replicate number & $\begin{array}{l}\text { Correlation equations between } \\
\text { time }(X \text { in hrs) and pileus } \\
\text { diameter in post-harvest } \\
\text { growth (Y in cm) of } 3 \\
\text { sporocarps }\left(N^{\circ} 7,8 \& 10\right) \text { used } \\
\text { as } 3 \text { replicates }\end{array}$ & $\begin{array}{l}\text { Potential } \\
(Y) \text { of prowth } \\
\text { diameter in } 36 \mathrm{hrs}\end{array}$ & $\begin{array}{l}\text { Average growth of } \\
\text { pileus diameter of } \\
\text { the } 3 \text { replicates: }(a+ \\
b+c): 3\end{array}$ \\
\hline$\left(\right.$ Sporocarp $\left.\mathrm{N}^{\circ} 7\right)$ & $Y_{7}=0.7+0.1 x$ & $4.3 \mathrm{~cm} \mathrm{(a)}$ & \\
\hline (Sporocarp No8) & $Y_{8}=1.98+0.225 x$ & $10.08 \mathrm{~cm}(\mathrm{~b})$ & $5.87 \mathrm{~cm}$ \\
\hline (Sporocarp $\mathrm{N}^{\circ} 10$ ) & $Y_{10}=-0.94+0.116 x$ & $3.23 \mathrm{~cm} \quad$ (c) & \\
\hline
\end{tabular}

\section{Statistical calculations}

Table 2 Statistical data and correlation equation between post-harvest growth of Termitomyces schimperi (sporocarp $\mathrm{N}^{\circ} 7=$ replicate $\mathrm{N}^{\circ} 1$ ) pileus diameter and time

\begin{tabular}{lllll}
\hline $\begin{array}{l}\mathbf{X} \text { (time of post- } \\
\text { harvest growth in } \\
\text { hrs) }\end{array}$ & $\begin{array}{l}\text { Y growth of } \\
\text { pileus diameter in } \\
\text { cm) }\end{array}$ & $\mathbf{X}^{\mathbf{2}}$ & $\mathbf{Y}^{\mathbf{2}}$ & $\mathbf{X . Y}$ \\
\hline 6 & 0.7 & 36 & & \\
12 & 2.2 & 144 & 0.49 & 4.2 \\
18 & 2.7 & 324 & 4.84 & 26.4 \\
24 & 3.7 & 576 & 7.29 & 48.6 \\
36 & 3.8 & 1296 & 13.69 & 88.8 \\
\hline
\end{tabular}

$$
\begin{array}{lll}
\mathbf{n}=\mathbf{5} & & \\
\sum X=96 & \sum X^{2}=2376 & \left(\sum X\right)^{2}=9216 \\
\sum Y=13.1 & \sum Y^{2}=40.75 & \left(\sum Y\right)^{2}=171.61 \\
\sum X Y=304.8 & &
\end{array}
$$


Means of $\mathrm{X}$ and $\mathrm{Y}$ from Table 2:

$\overline{\mathrm{X}}=\frac{\sum X}{n}=\frac{96}{5}=19.2$ and $=\frac{\sum Y}{n}=13.1: 5=2.62$

Coefficient a and $b$ of the regression line $(Y=a+b x)$ for the post-harvest growth of pileus diameter:

$b=\frac{\sum X . Y-\frac{\sum X \cdot \sum Y}{n}}{\sum X^{2}-\frac{\left(\sum X\right)^{2}}{n}}=\frac{304.8-\frac{96 \times 13.1}{5}}{2376-\frac{9216}{5}}=0.1$

$\mathrm{a}=\overline{\mathrm{Y}}-\mathrm{b} \overline{\mathrm{X}}=2.62-0.1 \times 19.2=0.7$

$\mathrm{Y}_{7}=\mathbf{0 . 7}+\mathbf{0 . 1 X}$

Correlation coefficient (r) :

$r=\frac{\sum X . Y-\frac{\sum X . \sum Y}{n}}{\sqrt{\left(\sum X^{2}-\frac{\left(\sum X\right)^{2}}{n}\right) \times\left(\sum Y^{2}-\frac{\left(\sum Y\right)^{2}}{n}\right)}}$
$r=\frac{304.8-\frac{96 \times 13.1}{5}}{\sqrt{\left(2376-\frac{9216}{5}\right) \times\left(40.75-\frac{171.61}{5}\right)}}$
$\mathbf{r}=\mathbf{0 . 9 1}$

Table 3 Statistical data and correlation equation between post-harvest growth of $T$. schimperi (sporocarp $\mathrm{N}^{\circ} 8=$ replicate $\mathrm{N}^{\circ}$ 2) pileus diameter and time.

\begin{tabular}{lllll}
\hline $\begin{array}{l}\text { X (time of post- } \\
\text { harvest growth } \\
\text { in hrs) }\end{array}$ & \begin{tabular}{l} 
Y $\begin{array}{c}\text { (growth of } \\
\text { pileus diameter } \\
\text { in cm) }\end{array}$ \\
\hline 6
\end{tabular} $\mathbf{X}^{\mathbf{2}}$ & $\mathbf{Y}^{\mathbf{2}}$ & $\mathbf{X . Y}$ \\
12 & 2.3 & 36 & 5.29 & 13.8 \\
18 & 5.3 & 144 & 28.09 & 63.6 \\
24 & 6.3 & 324 & 39.69 & 113.4 \\
36 & 8.3 & 576 & 68.89 & 199.2 \\
\hline
\end{tabular}

$\mathbf{n}=5$

$\sum X=96 \quad \sum X^{2}=2376 \quad\left(\sum X\right)^{2}=9216$

$\sum Y=31.5 \quad \Sigma Y^{2}=228.45 \quad\left(\sum Y\right)^{2}=992.25$

$\sum X Y=724.8$

Means of $X$ and $Y$ from Table 3:

$\overline{\mathrm{X}}=\frac{\sum X}{n}=\frac{96}{5}=19.2$ and $\overline{\mathrm{Y}}=\frac{\sum Y}{n}=\frac{31.5}{5}=6.3$

Coefficient a and $b$ of the regression line $(Y=a+b x)$ for the post-harvest growth of pileus diameter:

$b=\frac{\sum X . Y-\frac{\sum X \cdot \sum Y}{n}}{\sum X^{2}-\frac{\left(\sum X\right)^{2}}{n}}=\frac{724.8-\frac{96 \times 31.5}{5}}{2376-\frac{9216}{5}}=0.225$

$\mathrm{a}=\overline{\mathrm{Y}}-\mathrm{b} \overline{\mathrm{X}}=6.3-0.225 \times 19.2=1.98$

$Y_{8}=1.98+0.225 X$ 
Correlation coefficient (r) :

$$
\begin{aligned}
& r=\frac{\sum X . Y-\frac{\sum X . \sum Y}{n}}{\sqrt{\left(\sum X^{2}-\frac{\left(\sum X\right)^{2}}{n}\right) \times\left(\sum Y^{2}-\frac{\left(\sum Y\right)^{2}}{n}\right)}} \\
& r=\frac{724.8-\frac{96 \times 13.1}{5}}{\sqrt{\left(2376-\frac{9216}{5}\right) \times\left(228.45-\frac{992.25}{5}\right)}} \\
& \mathbf{r}=\mathbf{0 . 9 4 9}
\end{aligned}
$$

Table 4 Statistical data and correlation equation between post-harvest growth of $T$. schimperi (sporocarp $\mathrm{N}^{\circ} 10=$ replicate $\mathrm{N}^{\circ} 3$ ) pileus diameter and time.

\begin{tabular}{lllll}
\hline $\begin{array}{l}\mathbf{X} \text { (time of post- } \\
\text { harvest growth in } \\
\text { hrs) }\end{array}$ & $\begin{array}{l}\text { (growth of } \\
\text { pileus diameter in } \\
\text { hrs) }\end{array}$ & $\mathbf{X}^{\mathbf{2}}$ & $\mathbf{Y}^{2}$ & $\mathbf{X . Y}$ \\
\hline 6 & 0.1 & 36 & 0.01 & 0.6 \\
12 & 0.4 & 144 & 0.16 & 4.8 \\
18 & 0.9 & 324 & 0.81 & 16.2 \\
25 & 1.4 & 576 & 1.96 & 33.6 \\
36 & 3.6 & 1296 & 12.96 & 129.6 \\
\hline
\end{tabular}

$\begin{array}{lcr}\mathbf{n = 5} & & \\ \sum X=96 & \sum X^{2}=2376 & \left(\sum X\right)^{2}=9216 \\ \sum Y=6.4 & \sum Y^{2}=15.9 & \left(\sum Y\right)^{2}=40.96 \\ \sum X Y=184.8 & & \end{array}$

Means of $X$ and $Y$ from Table 4:

$\overline{\mathrm{X}}=\frac{\sum X}{n}=\frac{96}{5}=19.2$ and $\overline{\mathrm{Y}}=\frac{\sum Y}{n}=\frac{6.4}{5}=1.28$

Coefficient a and $b$ of the regression line $(Y=a+b x)$ for the post-harvest growth of pileus diameter:

$b=\frac{\sum X . Y-\frac{\sum X \cdot \sum Y}{n}}{\sum X^{2}-\frac{\left(\sum X\right)^{2}}{n}}=\frac{184.8-\frac{96 \times 6.4}{5}}{2376-\frac{9216}{5}}=0.116$

$\mathrm{a}=\overline{\mathrm{Y}}-\mathrm{b} \overline{\mathrm{X}}=1.28-0.116 \times 19.2=-0.94$

$Y_{10}=\mathbf{- 0 . 9 4}+\mathbf{0 . 1 1 6 X}$

Correlation coefficient (r) :

$r=\frac{\sum X . Y-\frac{\sum X \cdot \sum Y}{n}}{\sqrt{\left(\sum X^{2}-\frac{\left(\sum X\right)^{2}}{n}\right) \times\left(\sum Y^{2}-\frac{\left(\sum Y\right)^{2}}{n}\right)}}$

$r=\frac{184.8-122.88}{\sqrt{(532.8) \times(7.71)}}$

$\mathbf{r}=0.96$ 


\section{Histograms and correlation with regression lines}

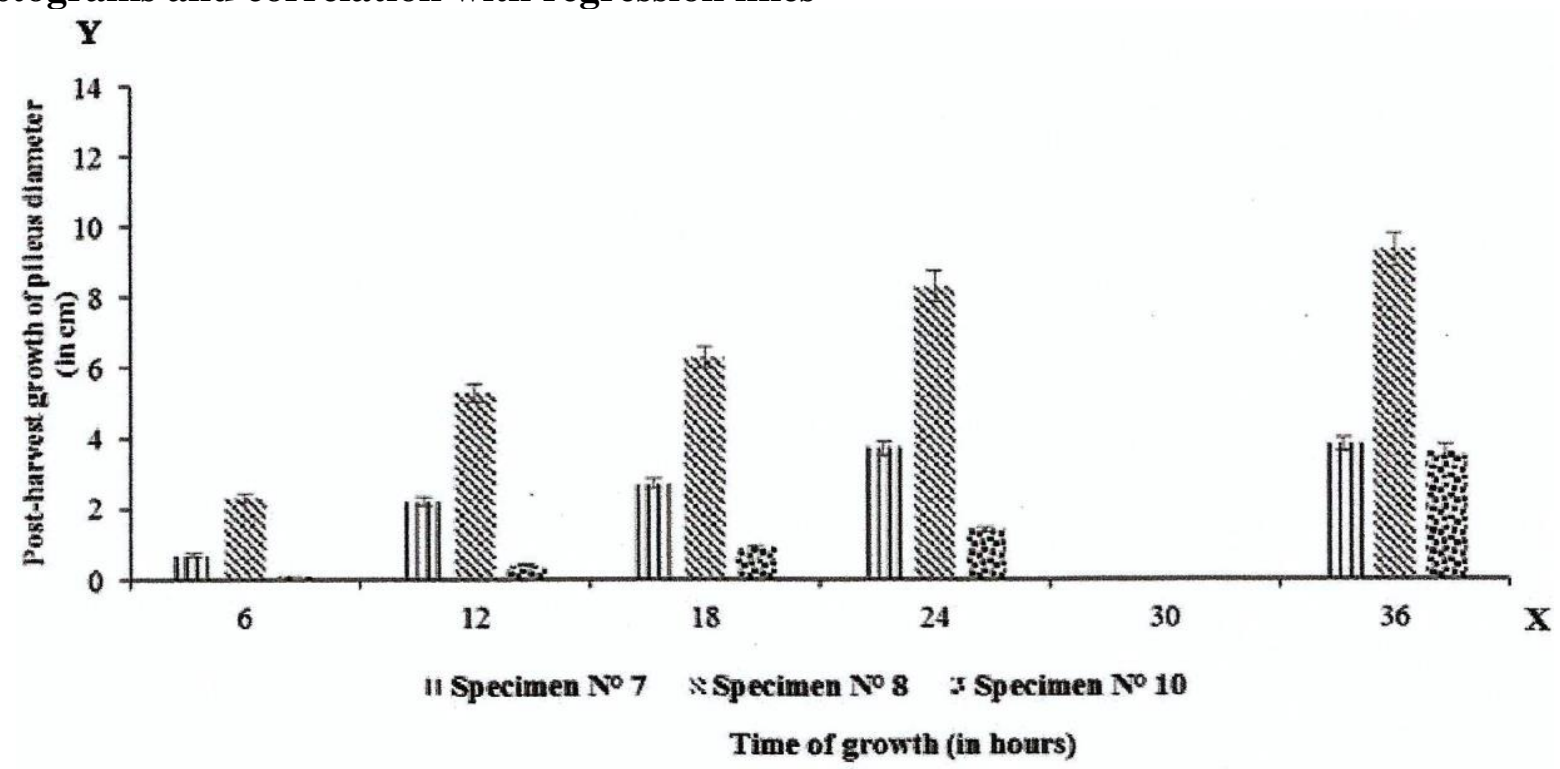

Fig. 3 - Histograms comparing the pileus diameter of three immature specimens $\left(\mathrm{N}^{\circ} 7,8 \& 10\right)$ of T. schimperi in post-harvest growth.

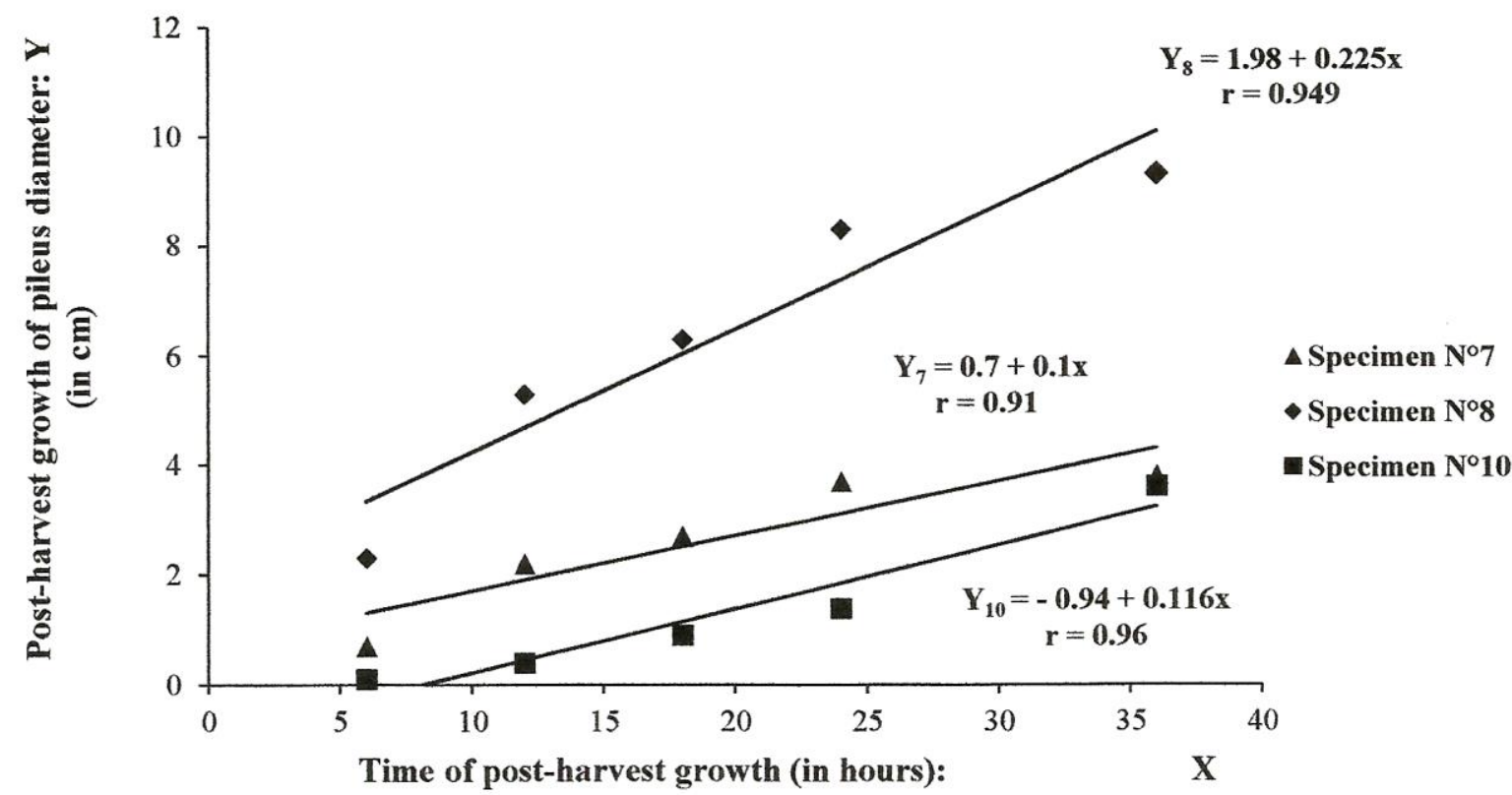

Fig. 4 - Correlation between growth of pileus diameter in $\mathrm{cm}$ and time of post-harvest growth in hours.

\section{Discussion}

Post-harvest growth and storage conditions of cultivated mushrooms have already been studied essentially in some few species of gill-fungi including Agaricus bisporus, Lentinus edodes (Berk.) Singer (shiitake) and Pleurotus spp. (Ares et al. 2007), but such studies have never before been carried out in the genus Termitomyces which are all symbiotic species of which sporocarps are not yet for the time-being artificially raised. According to Wichers et al. (2005), harvested mushrooms continue to grow as part of the ageing process and their post-harvest morphogenesis includes cap opening and stipe elongation that occur simultaneously. Considering Agaricus bisporus in particular which is the most cultivated species worldwide and featuring also among the most studied species in post-harvest growth, Hammond (1979) affirms that this species continues to 
develop after harvest as if it was still on the cultivation substrate (compost). On the sequence of events in post-harvest growth of Agaricus bisporus, Braaksma et al. (1998) says that "the stipe grows longitudinally, the cap continues to expand, gill formation occurs and spores are produced". Similar or different developments have also been observed in some few other species of gill-fungi studied by various authors including Ares et al. (2007), Henze (1989) and Moore (1984). The results of our study in $T$. schimperi generally match the above-mentioned observations of various authors, the main difference being that there is no stipe elongation in post-harvest growth of $T$. schimperi.

The study carried out here on the correlation of some post-harvest growth parameters in vitro of T. schimperi is the first in its kind in this genus. T. schimperi was chosen as model for the study for several reasons including that it features with T. titanicus Pegler \& Piearce and T. letestui (Pat.) R. Heim among the largest and most fleshy species of this genus, and are therefore highly preferred by collectors and consumers. Considering that both species and others in the genus are not yet cultivated artificially, scientists still rely only on luck to collect them on the field where they could be found mature or still immature (Mossebo et al. 2002, 2017), or even just at the primordium (Aanen et al. 2002, Frøslev et al. 2003) stage. Immature sporocarps of some other Termitomyces species and several other gill-fungi could therefore also be collected and set in specific environments in the laboratory for post-harvest growth enabling their studies. Another reason for choosing T. schimperi as model in this study is that, as in Agaricus bisporus (Ares et al. 2007, Hammond 1979, Braaksma et al. 1998), the evolution of the pileus morphology of T. schimperi at different steps of growth is suitable for the research question investigated here. However, one of the major differences noted with the post-harvest growth of Agaricus bisporus during which the stipe continues to grow according to Hammond (1979) and Braksma et al. (1998), is that the size of the stipe of T. schimperi remains constant and does not evolve in post-harvest growth. In fact, in $T$. schimperi, only the pileus enlarges and changes morphology. One of our key results is the determination of the maximum time of post-harvest growth of this species established to about 36 hrs. This is however just an indicative figure which could still vary a little bit depending on the state of the sporocarp used which is in close relationship with several other parameters including its state of freshness that depends on water and other reserve substances content at the start of postharvest growth experiment. About Agaricus bisporus, Burton (1988) affirms that "proteolytic enzymes release amino acids from proteins that provide fungi the necessary nutrients and energy for their morphological changes, especially sporulation". This process could be similar in $T$. schimperi considering that according to Kansci et al. (2003) who investigated six different species of Termitomyces, T. schimperi shows: $83.75 \%$ of water, a protein content of $2.35 \mathrm{~g}$ per $100 \mathrm{~g}$ of fresh weight and $14.48 \mathrm{~g}$ per $100 \mathrm{~g}$ of dry weight, the highest amount of carbohydrates $(57.42 \mathrm{~g}$ per $100 \mathrm{~g}$ of dry weight) and second highest provider of energy (210.6 kJ per $100 \mathrm{~g}$ of fresh weight). About morphological changes, the high amount of carbohydrates and energy could also account for the relatively fast opening of pileus hemenophore in T. schimperi, where this was found to occur 24 to $36 \mathrm{hrs}$ (Fig. 2) after launching the post-harvest growth experiment, whereas according to Wichers et al. (2005), a minimum of 3 days ( $72 \mathrm{hrs)} \mathrm{is} \mathrm{needed} \mathrm{for} \mathrm{the} \mathrm{cap-opening} \mathrm{of} \mathrm{fast} \mathrm{growing}$ strains of Agaricus bisporus. The above mentioned parameters surely account for the three different correlation equations $\left(\mathrm{Y}_{7}=0.7+0.1 \mathrm{x} ; \mathrm{Y}_{8}=1.98+0.225 \mathrm{x} ; \mathrm{Y}_{10}=-0.94+0.116 \mathrm{x}\right)$ obtained for the 3 replicates (sporocarps) of $T$. schimperi with quite different patterns (Fig. 4) of post-harvest growth giving way to a wide range of variation of additional growth $(3.23 \mathrm{~cm}$ to $10.08 \mathrm{~cm})$ in pileus diameter. Correlation equations between time and growth of carpophores have earlier (Ayissi 2015, Ayissi et al. 2015) been computed in Ganoderma resinaceum Boud. but the aim here was rather to determine the optimum time of spore production and collection on the field.

In conclusion, the experiment carried out here with $T$. schimperi could serve as a model for other species of gill-fungi in particular, considering that field mycologists, researchers, mushrooms collectors and consumers sometimes find them only at an immature stage of growth on the field, whereas taxonomist mycologists and researchers in fungal sciences in general would prefer more mature sporocarps in order to properly carry out macro- and micromorphological studies, as well as 
collecting spore-prints and extracting DNA for molecular phylogeny, which in gill-fungi in particular, is most often done from mature lamellae.

\section{Acknowledgements}

The authors thank the "Agence Universitaire de la Francophonie (AUF), Bureau Afrique centrale et des grands lacs (BACGL)" for offering to our laboratory a research grant in the framework of "Projet N ${ }^{\circ}$ BACGL 2014-46 du 19/12/2014" thanks to which part of the material for field and lab work was acquired. The authors also thank the Cameroon Ministry of Higher Education (MINESUP) for the special support fund for research through which we received the grant $\mathrm{N}^{\circ} 16-00433 / \mathrm{MINESUP/SG} / \mathrm{CS}$ thanks to which the field work was carried out. The authors are also very grateful to Pr. Kekeunou Sévilor, Biostatistician at the Faculty of Science of the University of Yaoundé 1 and to Dr. Onka Mouanda Vivien, Statistics Engineer at the Sub-Regional Institute of Statistics and Applied Economics (ISSEA) for central Africa in Yaoundé, Cameroons, who both assisted us in computing the statistical calculations and correlation equations.

\section{References}

Aanen DK, Eggleton P, Rouland-Lefèvre C, Frøslev TG et al. 2002 - The evolution of fungusgrowing termites and their mutualistic fungal symbionts. Proceedings of the National Academy of Sciences, USA 99, 14887-14892.

Ares G, Lareo C, Lema P. 2007 - Modified atmosphere packaging for postharvest storage of mushrooms. Invited Review in "Fresh produce", Global Science Books. pp. 32-34.

Braaksma A, Van Doorn AA, Kieft H, Van Aelst AC. 1998 - Morphometric analysis of ageing mushrooms (Agaricus bisporus) during postharvest development. Postharvest Biol. Technol. $10,127-134$.

Burton KS. 1988 - The effects of storage and development on Agaricus bisporus proteases. Journal of Horticultural Science 63, 103-108.

Burton KS, Frost CE, Nichols R. 1987 - A combination of plastic permeable films system for controlling post-harvest mushroom quality. Biotechnology letters 9, 529-534.

Frøslev TG, Aanen DK, Læssøe T, Rosendahl S. 2003 - Phylogenetic relationships of Termitomyces and related taxa. The British Mycological Society. Mycological Research 107 (11), 1277-1286. DOI: 10.1017/S0953756203008670.

Hammond JBW. 1979 - Changes in composition of harvested mushrooms (Agaricus bisporus). Phytochemistry 18, 415-418.

Heim R. 1977 - Termitomyces et champignons, les champignons termitophiles d'Afrique noire et d'Asie méridionale. Edition Boubée, Paris. 205 pp.

Heim R. 1958 - Flore iconographique des champignons do Congo. Termitomyces: $7^{\mathrm{e}}$ fascicule Ministère de l'Agriculture, Bruxelles. pp. 139-152.

Heim R. 1942 - Nouvelles études descriptives sur les agarics termitophiles d'Afrique tropicale. Archives du Muséum Nationale d'Histoire Naturelle Paris, 18 (ser. 6), 107-166.

Henze J. 1989 - Storage and transport of Pleurotus mushroom in atmosphere with high $\mathrm{CO}_{2}$ concentrations. Acta hortucularae 258, 579-584.

Kansci G, Mossebo DC, Selatsa AB, Fotso M. 2003 - Nutrient content of some mushroom species of the genus Termitomyces consumed in Cameroon. Nahrung-Food 47, 213-216.

Don' Ayissi MB, Mossebo DC, Machouart MC, Kansci G et al 2014 - A new method by correlation to forecast the optimal time of spore-prints production and collection on sporocarps of Ganoderma resinaceum Boud. (Basidiomycota) on natural substrate. Mycosphere 5 (6), 758-767. Doi: 10.5943/mycosphere/5/6/6.

Kengni Ayissi MB. 2015 - Contribution à la taxonomie et Phylogénie moléculaire (ITS-ADNr) des Ganoderma (Basidiomycota) d'Afrique centrale et détermination par corrélation des paramètres bioclimatiques de libération des spores des carpophores de Ganoderma resinaceum Boud. Thèse de Doctorat-Ph.D. Université de Yaoundé 1, Cameroon. 176 pp. 
Kirk PM, Cannon PF, Minter DW, Stalpers JA. 2008 - Ainsworth \& Bisby's Dictionary of the Fungi, 10th Edition. CABI Europe - UK, 771 pp.

López-Briones G, Varoquaux P, Yves C, Bouquant J et al. 1992 - Storage of common mushroom under controlled atmospheres. International Journal of Food Science and Technology 27, 493-505.

López-Briones G, Varoquaux P, Bureau G, Pascat B. 1993 - Modified atmosphere packaging of common mushrooms. International Journal of Food Science and Technology 28, 57-68.

Moore D. 1984 - Development biology of the coprinus cinereus carpophore: metabolic regulation in relation to cap morphogenesis. Experimental Mycology 8, 283-297.

Mossebo DC. 2000 - Ecology and systematic revision of the genus Termitomyces (tropical Basidiomycetes) in Cameroon. Abstract XVI ${ }^{\text {th }}$ AETFAT Congress in Brussels, Belgium, August $28^{\text {th }}$-September $2^{\text {nd }}, 2000$. Scripta Botanica Belgica 20, 57-58.

Mossebo DC. 2002 - Contribution to the knowledge of Termitomyces (tropical Basidiomycetes) from Cameroon: Ecology and systematics. Poster: 7th International Mycological Congress (IMC7) (ii), Oslo, Norway, 11-17th August 2002, Abstract in "IMC7 BOOK OF ABSTRACT"' pp. 221-222.

Mossebo DC, Amougou A, Atangana RE. 2002 - Contribution à l'étude du genre Termitomyces (Basidiomycètes) au Cameroun: Ecologie et systématique. Bulletin de la Société Mycologique de France 118(3), 195-249.

Mossebo DC, Courtecuisse R, Vánky K. 2006 - New records of Termitomyces (Basidiomycete) from Cameroon and central Africa: Taxonomy, ecology and phylogeny. Poster: $8^{\text {th }}$ International Mycological Congress (IMC8) (iii), Cairns, Australia, $21^{\text {st }}-25$ th August 2006, Abstract (PS1-16-0112) in "IMC8 ABSTRACTS BOOK 1".

Mossebo DC, Njouonkou AL, Piatek M, Kengni Ayissi MB et al. 2009 - Termitomyces striatus f. pileatus $\mathrm{f}$. nov. and $\mathrm{f}$. brunneus f. nov. from Cameroon with a key to Central African species. Mycotaxon 107, 315-329.

Mossebo DC, Njouonkou AL. 2010 - Répartition géographique et valeur nutritive de quelques espèces de Termitomyces (Basidiomycètes) du Cameroun. In: X Van der Burgt, J. Van der Maesen et Onana J. M. (eds), Proceedings of the $16^{\text {th }}$ AETFAT Congress, Yaoundé, Cameroon. Systématique et conservation des Plantes Africaines. Royal Botanic Garden, Kew. pp. 151-157.

Mossebo D.C, Flavien P.E. Essouman, Baudelair M. Kengni Ayissi, Nzapena'A Tetang et al. 2011 - Termitomyces infundibuliformis sp. nov. et T. striatus $\mathrm{f}$. camerunensis $\mathrm{f}$. nov. décrits du Cameroun. Clé d'identification des Termitomyces d'Afrique centrale. Bulletin de la Société Mycologique de France 127 (1-2): 153-168.

Mossebo DC, Essouman EPF, Machouart M, Gueidan C. 2017 - Phylogenetic relationships, taxonomic revision and new taxa of Termitomyces (Lyophyllaceae, Basidiomycota) inferred from combined nLSU- and mtSSU-rDNA sequences. Phytotaxa 321(1): 71-102. Doi: http://dx.doi.org/10.11646/phytotaxa.321.1.3.

Natarajan K. 1979 - South Indian Agaricales V: Termitomyces heimii. Mycologia 71, 853-855

Otieno NC. 1964 - Contribution to the knowledge of Termite fungi in East Africa. The genus Termitomyces Heim. Proceedings of the East African Academy Vol. II, 108-120.

Oyetayo VO. 2012 - Wild Termitomyces Species Collected from Ondo and Ekiti States are more related to African Species as Revealed by ITS Region of rDNA. The Scientific World Journal, 1-5. Doi: 10.1100/2012/689296.

Pegler DN. 1977 - A preliminary Agaric flora of East Africa. Kew Bulletin, Add. Series 6. 615 pp. Pegler DN, Vanhaecke M. 1994 - Termitomyces of Southeast Asia. Kew Bulletin 49 (4), 717-736.

Piearce GD. 1987 - The genus Termitomyces in Zambia. Mycologist 1, 111-116.

Rouland-Lefevre C, Ngor Diouf M, Brauman A, Neyra M. 2002 - Phylogenetic Relationships in Termitomyces (family Agaricaceae) based on the nucleotide Sequence of ITS: A first approach to elucidate the Evolutionary History of the Symbiosis between Fungus-Growing 
Termites and their fungi. Molecular Phylogenetics and Evolution 22(3), 423-429. Doi: 10.1006/mpev.2001.1071.

Roy S, Anantheswaran RC, Beelman RB. 1996 - Modified atmosphere and modified humidity packaging of fresh mushrooms. Journal of Food Science 61, 391-397.

Saarimäki T, Härkönen M, Mwasumbi L. 1994 - Tanzanian mushrooms and their uses. 3. Termitomyces singidensis, sp. nov. Karstenia 34, 13-20.

Saré IC, Ndir MS, Manga A, Ndiaye M. 2014 - Molecular characterization of wild Senegalese voucher belonging to the Agaricus, Ganoderma and Termitomyces genera. Evidences of new species phylogenetically distant from described ones. Journal of biological \& scientific opinion 2(2), $124-131$. ISSN 2321-6328.

Sawhasan P, Worapong J, Vinijsanun T. 2011 - Morphological and Molecular studies of selected Termitomyces species collected from 8 districts of Kanchanaburi Province, Thailand. Thai Journal of Agricultural Science 44(3), 183-196.

Singer R. 1986 -The Agaricales in the modern taxonomy. $4^{\text {th }}$ edt. 981p.

Tang BH, Wei TZ, Yao YJ. 2005 - Type revision of three Termitomyces species from India. Mycotaxon 94, 93-102.

Tang BH, Wei TZ, Yao YJ. 2006 - Revision of Termitomyces species originally described from China. Mycotaxon 95, 285-293.

Tano KT, Arul G, Doyon, Castaigne F. 1999 - Atmospheric composition and quality of fresh mushroom in modified atmosphere packages as affected by storage temperature abuse. Journal of Food Science 64, 1073-1077.

Taprab Y, Ohkuma M, Johjima T, Maeda Y et al. 2002 - Molecular Phylogeny of Symbiotic Basidiomycetes of Fungus-growing Termites in Thailand and Their Relationship with the Host. Bioscience, Biotechnology and Biochemistry 66 (5), 1159-1163.

Turnbull E, Watling R. 1999 - Some records of Termitomyces from the old world rainforests. Kew Bulletin 54, 731-738.

Van der Westhuizen GCA, Eicker A. 1990 - Species of Termitomyces occurring in South Africa. Mycological Research 94 (7), 923-937.

Wei TZ, Yao YJ, Wang B, Pegler DN. 2004 - Termitomyces bulborhizus sp. nov. from China, with a key to allied species. Mycological Research 108 (12), 1458-1462.

Wichers HJ, Soler-Rivas C, Danai O, Nerya O et al. 2005 - Post Harvest quality of Agaricus bisporus mushrooms. Acta. Edulis. Fungi. 12 (supplement), 475-481. 